\title{
Implementation of HbA1c point of care testing in 3 German Medical Practices: Impact on processes, physician, staff and patient satisfaction.
}

Oliver Schnell', Susanne Emmerich

'Sciarc GmbH, Schorner Str. 1a, 82065 Baierbrunn, Germany; 'Alere GmbH, Am Wassermann 28, 50829 Köln,

\section{Background and aims:}

Medical practices face challenges of time and cost pressures with scarce resources. Once properly implemented into the practice workflow, point of care testing (POCT) has the potential to accelerate and streamline processes compared to central lab testing and thus positively impact operational efficiencies, physician, staff and patient satisfaction.

The objective of this study was to evaluate the effects of introducing HbA1c Point-of-Care testing (POCT; Alere Afinion ${ }^{\text {Tw }}$ AS100 Analyzer) in medical practices specialized in diabetes.

\section{Materials and methods:}

Three German medical practices that manage 400, 550 and 950 diabetes patients per year participated in this evaluation (Table 1). In all of these practices, the general workflow prior to implementation of POCT involved two visits per quarter per patient; (one for the venous blood sampling and a second for the consultation with the physician after lab values are available). The workflow for 100 patients before and for 100 patients after implementation of POCT was evaluated in each practice. The time required for process steps (patient registration at reception desk, scheduling of visits, filling out of lab order forms, venous and capillary blood collection and weekly control measurement for POCT) were measured in each practice. Patient (278 patients), office staff (9 persons) and physician (5 persons) satisfaction was assessed with questionnaires and in interviews.

\section{Results:}

\section{Practice processes}

After implementation of POCT, the number of required visits scheduled was reduced by $80 \%$ ( $88 \%$ vs. $17.6 \%, p<0.0001$ ) and the number of required venous blood collections was reduced by $75 \%$ ( $91 \%$ vs. $23 \%, p<0.0001)$. In $82 \%$ vs. formerly $13 \%$ of patients the $\mathrm{HbA} 1 \mathrm{c}$ results and therapy could be directly discussed during the first office visit $(p<0.0001)$ (Figure 1). In two of the practices the POCT process resulted in significant time savings, approximately 22 and 24 working days (respectively), per 1000 patients per year (95\% Cl 2-46; 95\% Cl 10-44) (Figure 2). However, the time spent on capillary blood sampling in the third practice was almost 4 times that of the other practices and as such no time savings was associated with POCT implementation in this practice.

\section{Patient, staff and physician satisfaction}

The majority (61\%) of patients found the capillary blood collection more pleasant (with 27\% finding no difference) and $83 \%$ seeing an advantage in the immediate availability of the HbA1c results. It was appreciated that one office visit could be avoided.

All staff members found the POCT measurement easy to perform and most found the capillary blood collection easier and faster than the venous blood collection. All staff members experienced a relief of burden after implementation of POCT.

All 5 physicians found that POCT HbA1c implementation improved the practice workflow. Asked to rank their answer on a scale with 1 being the lowest and 10 the highest value, 3 chose the value 8 and 2 the value 9 . Asked whether they experienced a relief of burden for the office and the patients 1 physician chose the value 7 , and 2 each the values 8 and 9 (Table 2). POCT was found to be especially important for referred patients, who arrive for their first visit without prior lab values. 
Table 1: Characterization of practices

\begin{tabular}{|c|c|c|c|}
\hline & Office 1 & Office 2 & Office 3 \\
\hline \multirow[t]{2}{*}{ Region } & Bonn & Bochum & $\begin{array}{l}\text { Bergisch } \\
\text { Gladbach }\end{array}$ \\
\hline & $\begin{array}{l}\text { Joint practice for } \\
\text { internal and general } \\
\text { medicine with a } \\
\text { diabetological } \\
\text { focus }\end{array}$ & $\begin{array}{l}\text { General } \\
\text { practice } \\
\text { with a } \\
\text { diabetological } \\
\text { focus }\end{array}$ & $\begin{array}{l}\text { Joint practice } \\
\text { specialized } \\
\text { in internal } \\
\text { medicine/ } \\
\text { diabetology }\end{array}$ \\
\hline $\begin{array}{l}\text { Number of } \\
\text { diabetes } \\
\text { patients (per } \\
\text { year) }\end{array}$ & 400 & 550 & 950 \\
\hline $\begin{array}{l}\text { Number } \\
\text { of HbA1c } \\
\text { measurements } \\
\text { (per year) }\end{array}$ & 1600 & 2200 & 3800 \\
\hline $\begin{array}{l}\text { Number of } \\
\text { physicians }\end{array}$ & 3 & 2 & 2 \\
\hline Number of staff & $6^{1 / 2}$ & 8 & 9 \\
\hline
\end{tabular}

Figure 1: Improvement of practice processes

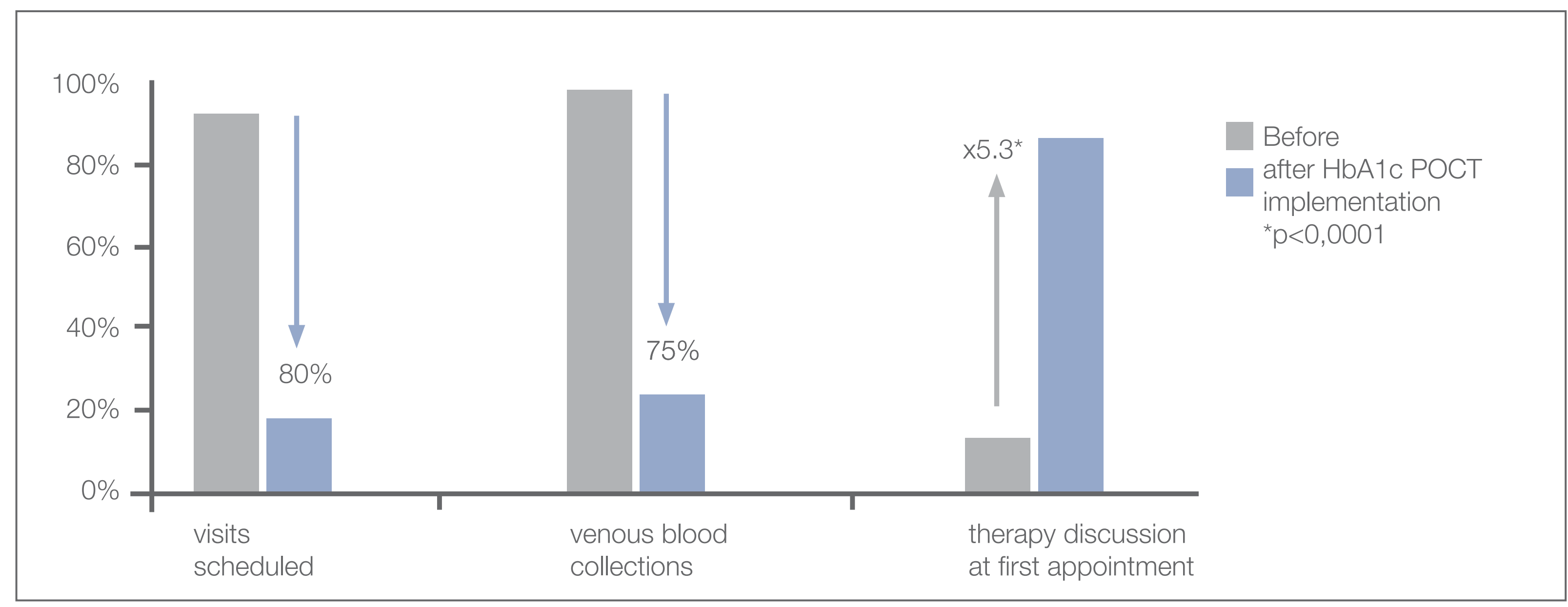


Figure 2: Time Savings

\begin{tabular}{|ccccc|}
\hline Practice & 1 & $\begin{array}{c}22 \\
\text { days }\end{array}$ & $95 \%$ Cl2-46 & $\begin{array}{l}\text { based on } 40 \text { hour work week; } \\
\text { calculated for 1000 pateints having } 4 \\
\text { HbA1c measurements per year. }\end{array}$ \\
Practice & 2 & $\begin{array}{c}0 \\
\text { days }\end{array}$ & & \\
Practice & 3 & $\begin{array}{c}24 \\
\text { days }\end{array}$ & $95 \%$ Cl10-44 & \\
\hline
\end{tabular}

\section{Table 2: Physician satisfaction}

\begin{tabular}{|c|c|c|c|c|c|c|c|c|c|c|c|c|}
\hline $\begin{array}{l}\text { Scale } \\
1=\text { Lowest } \\
10=\text { Highest Value }\end{array}$ & & 1 & 2 & 3 & 4 & 5 & 6 & 7 & 8 & 9 & 10 & mean \\
\hline $\begin{array}{l}\text { 1) Did the } \\
\text { immediate } \\
\text { availability } \\
\text { of HbA1c } \\
\text { results lead to } \\
\text { an improved } \\
\text { practice } \\
\text { workflow? }\end{array}$ & $\begin{array}{l}\text { yes }=5 \\
\text { no }=0\end{array}$ & & & & & & & & 3 & 2 & & 8,4 \\
\hline $\begin{array}{l}\text { 2) Did you } \\
\text { experience } \\
\text { a relief of } \\
\text { burden? }\end{array}$ & $\begin{array}{l}\text { yes }=5 \\
\text { no }=0\end{array}$ & & & & & & & 1 & 2 & 2 & & 8,2 \\
\hline $\begin{array}{l}\text { 3) Did the } \\
\text { immediate } \\
\text { availability } \\
\text { of HbA1c } \\
\text { values result } \\
\text { in treatment- } \\
\text { improvement? }\end{array}$ & $\begin{array}{l}\text { yes }=5 \\
\text { no }=0\end{array}$ & & & & & 1 & & 1 & 1 & 1 & & 7,25 \\
\hline $\begin{array}{l}\text { 4) How do } \\
\text { you rate the } \\
\text { implementation } \\
\text { of HbA1c } \\
\text { measurement } \\
\text { using POCT } \\
\text { overall? }\end{array}$ & $\begin{array}{l}\text { yes }=5 \\
\text { no }=0\end{array}$ & & & & & & & & 2 & 2 & 1 & 8,8 \\
\hline
\end{tabular}




\section{Conclusion:}

This study demonstrated that the implementation of POCT for HbA1c lead to an improved and more efficient work flow in outpatient medical practices. It was appreciated by patients and well accepted by office staff and physicians, who experienced the POCT implementation as a relief of burden.

This study was funded by: Alere GmbH, Cologne, Germany 